\title{
HONOUR KILLING IN INDIA
}

\section{NIRU SHARAN}

Associate Professor, Amity Law School, Noida, Uttar Pradesh, India

ABSTRACT
Caught in the middle of an ancient culture dating back several millenniums juxtaposed with modernization and
globalization, India has witnessed a paradigm shift in social values and principles. International media has constantly
induced liberal thinking into the newer generations which in turn has made them challenge the norms of old society that
have been imposed through strict vigilance. One of the unfortunate outcomes of such rebellion has materialized in the
form of honour killings.
KEYWORDS: Acts \&Honour Killings

Received: Aug 06, 2018; Accepted: Sep 26, 2018; Published: Feb 25, 2019; Paper Id.: IJPSLIRJUN20196

\section{INTRODUCTION}

Honour killings are incidents of murder in the name or in the belief of preserving honour of the family or community. An honor killing in principle is the homicide of a member of a family or social group by other members, due to the perpetrators' belief that the victim has brought shame or dishonor upon the family or community, for reasons such as refraining from solemnizing an arranged marriage, being in a relationship that is looked down upon by the community, having sexual relations outside of the wedlock, becoming the victim of rape, adopting mannerisms and behaviour deemed to be against the order of nature, such as homosexuality. ${ }^{1}$

The smallest unit in the society is a family. Each family has its own concept of honour, based closely in the society and culture that they have been brought up in and live in. To murder in the name of such belief of preserving honour, would amount to an honour killing.

Honour Killings are crimes against women and in certain circumstances even against men for their alleged or actual behavior that leads to the depletion of their families or communities honour in the eyes of the public (Hassan 1995). ${ }^{2}$ Honour killings are murders by families on family members who are said to have brought shame on the honour and name of family (Sheri \& Bob Stritof 2005). ${ }^{3}$ An honour killing can be said to be an act by which "a male member of the family kills a female relative for tarnishing the family image" (Free Dictionary by Farlex 2007). Honour killings are also defined as "the purposeful pre-planned murder, generally of a woman, by or at the command of members of her family stimulated by a perception that she has brought shame on the family" (Oxford Dictionary of Law Enforcement 2007).

"Honour killings can also be described as extra-judicial punishment of a female relative for assumed

\footnotetext{
1"Honor killing: Definition and More from the Free Merriam-Webster Dictionary". Merriam-webster.com. Decemb 2013.

${ }^{2}$ Yasmeen Hassan "The haven becomes hell: a study of domestic violence in Pakistan." August 16, 1995.72 p. (S Bulletin), Johns Hopkins Bloomberg.

${ }^{3}$ Sheri \& Bob Stritof.Marriage. Available at http://marriage.about.com/od/historyofmarriage/g/marriage.htm.
} 
sexual and marriage offences. These offences, which are considered as a misdeed or insult, include sexual faithlessness, marrying without the will of parents or having a relationship that the family considers to be inappropriate and rebelling against the tribal and social matrimonial customs. These acts of killing women are justified on the basis that the offence has brought dishonour and shame to family or tribe" (Amnesty International 1999). ${ }^{4}$

According to another Amnesty International Report "the regime of honour is unforgiving: women on whom suspicion has fallen are not given an opportunity to defend themselves, and family members have no socially acceptable alternative but to remove the stain on their honour by attacking the woman" (Amnesty International 2001). ${ }^{5}$

A common fallacy is that Honour Crimes are perpetrated at the hands of illiterate people, "There are also perpetrators who are well educated university graduates. Of all those surveyed, 60 percent are either high school or university graduate or at the very least literate" as per a study by Dicle University (Gezer 2001).

In many families girls are not allowed the freedom to roam idle outside of the home. They are required to return home immediately on the completion of their school/college/work hours and remain indoors for the remaining portion of the day. It is also not uncommon for the girl child to be denied education altogether because of her being a female. Hence, a nexus can also be drawn between forced marriages and honor killings. In the Indian society, a long lasting tradition of choosing the husband for the daughters of the house has persisted. Meetings are organized with families of similar profession, caste, locality, social status and the like, to find a suitable match for the females of the household. In certain families, post the meeting, the girls either choose the husbands for themselves, or enter into a 'willful arranged marriage'. On the other hand if the same is denied to them, then they enter into a 'forced arranged marriage'. Forced arranged marriages could turn out to be a blissful event, or not. In the event of a forced marriage not turning out to be a pleasant one, girls often lead very difficult lives characterized by marital rape and hostile conditions. To avoid the same, girls prefer to choose their own husbands which often results in violent consequences.

It can be safely said that Honour Killings are acts in which ones belief of honour results in the criminal act of murder or homicide. Honour in subjective. It is a relative term and varies with cultural belief. It is an abstract concept that deals with the worthiness and standing of oneself and is always in contrast to the other members of the society.

Acts of honour killings are usually against female members of the family and are committed by authoritarian male members. It roots in the age old concept of female insubordination within the family that leads to the commission of such crimes. In such social conditions the male members deem upon themselves the responsibility of ensuring that the female members are acting within the permissible range of conduct approved by them. Honour Killings are the graver consequences of the violative acts of the aforementioned range of conduct by female members of the community. ${ }^{6}$

However, women are not the sole victims of the brunt of honour killings. Men can also be murdered out of incidental rage against the female victims as has been reported in various incidents. A common example would be wedlock out of the caste barrier. In such instances along with the woman often the male member is murdered along with the girl.

\footnotetext{
${ }^{4}$ Amnesty $\quad$ International, Amnesty International $\quad$ Report 1999 - Belize, 1 January 1999, available at: http://www.refworld.org/docid/3ae6aa0644.html

${ }^{5}$ This report is one of a series of publications issued by Amnesty International as part of its worldwide campaign against torture launched in 2000. These include Hidden Scandal, Secret Shame-Torture and Ill-treatment of Children (2000) and Stopping the Torture Trade (2001b). Online versions available as ACT 40/038/2000 and ACT 40/002/2001, respectively at http://www.amnesty.org.

6"Violence Against Women and "Honor Crimes". Human Rights Watch.Retrieved 6 April 2001.
} 
Furthermore, there exists compelling data that highlights that a vast number of men have been victimized for the homosexual tendencies. ${ }^{7}$ Homosexuality which has been under much debate recently because of its constitutional legitimacy, is another pressing concern for creating grounds for honour killings.

The Supreme Court chose to not deal with the issue of homosexuality being against the course of nature in the Naz Foundation case, ${ }^{8}$ and left a large void. Because of the low levels of tolerance on the subject of homosexuality, homosexual men are forced to live or carry out their sexual needs in the shadows of society. Most of them pretend to lead normal lives or get married to women while maintaining their homosexual relations under a cloak. These secret lives of homosexual men either comes into the limelight by voluntary confession, or by way of accident. Irrespectively, it rarely leads to humane consequences.

Human beings are social animals. And social animals do not take very well to members of their society that have quirks or different ways. There are many types of quirks and varying with their intensity and perception, their intolerance is expressed. There have been a plethora of reports that suggest that not only homosexuals, but men with varied sexual orientations like eunuchs for example face the violent wrath of the illiterate society.

\section{A HISTORICAL PERSPECTIVE OF HONOUR KILLING IN INDIA}

To understand the nitty-gritties of honour crimes in India, it is of utmost importance to look at the practices and customs of our ancient society. There are many religious and customary scriptures that explain the power and pangs of women in the ancient Indian society. A historical analysis shows developments in the mindsets of societies and provides a rational explanation to the acts undertaken by them.

First and foremost would be Manu and his teachings. Manu is regarded as the progenitor of humanity in Indian culture. His teachings have a superior imposition over and above all other smritis. Manu in his teachings laid down that a man must exert his forces and powers in order to protect the women in his family[Manu (IX.15-16) lays down that every man should exert himself strenuously to guard them (Chakravarti, 2003, p. 71)]; that a woman belongs to her father during her childhood, her husband during her youth, to her sons on the death of her husband and to god on meeting death itself, therefore a woman should never be independent [Manusmriti.V.148 provides that in childhood, a female must be subject to her father, in youth to her husband, when her Lord is dead to her sons; a woman must never be independent]; that a woman must never abandon her father, husband and sons or she would bring contempt to the family[Manusmriti.V.149 provides that the woman must not seek to separate herself from her father, husband or sons. By leaving them, she would make both, her own and her husband's families contemptible]; and that the father, or the brother with the fathers consent can bind the woman to a man of their desire, to whom she shall respond, and on the event of his death never insult his memory[Manusmriti.V.151 further lays down that him to whom her father may give her or her brother with the father's permission, she shall obey as long as he lives and when he is dead, she must not insult his memory (Buhler, 1990, p. 195)

This presents a disturbing picture of how women are expected to be treated as cattle by the men in the household and are expected to blindly serve their wishes and expectations. Manu, who is regarded as the apex authority on Hindu law himself expressly stated that women were always to be subjugated and their freedoms curtailed by men. A women was to be made answerable to her father in her childhood, husband in her youth and sons on the death of her husband.

\footnotetext{
${ }^{7}$ VisheshKocchar. Teen Lovers killed in India. Ibnlive. September 18, 2008 . Available at http://ibnlive.in.com/news/honour-killing-teen-lovers-murdered-near-noida/73859-3.html

${ }^{8}$ Suresh Kumar Kaushal v. Naz Foundation, [(2014)1SCC1].
} 


\section{MEASURES THAT NEED TO BE TAKEN TO PREVENT AND ERADICATE HONOUR KILLINGS FROM INDIA}

\section{Enactment of a New Law for Honour Killings}

Just the way separate laws have been enacted in addition to prior existing ones, for instance the law on prevention of domestic violence, new laws should be made to exclusively deal with honour killings. Honour killing are a different kind of murder and the same needs to be recognized by the law. The bigger facet of honour killing that needs to be dealt with is the fact that unlike regular murders, honour killings enjoy the support and help of the local community.

Laws have a major impact on the mindset of the people. People embrace the superiority of laws and legislative actions guide the mindsets of the masses. For instance, in the Naz Foundation case, the Delhi High court decriminalized homosexuality. It did not take long for people to step out in favour of homosexuals, and the perception of the people who habituate in societies with homosexual individuals opened their minds to such practices and accepted that such activities do not have to be against the course of nature. This did not last very long as the Supreme Court overruled the judgment of the high court, but the impact of the rulings of the courts could be notice with the media reaction to it.

The same applies to honour killings. There are not only individuals but communities of people who feel that killing members of the family in the name of honour is justified and should not be discouraged. If the law is passed that specifically deals with honour crimes, these individuals, though definitely not all of them, will have no option but to respect the law and realize that honour killings are in fact being frowned upon in the country.

\section{Establishment of Fast Track Courts to Deal Exclusively with Honour Killings}

The biggest problem in the Indian judicial system is the lack of faith in the judiciary. The reason for the lack of faith is not the ineffective or lack of predominance of judicial spirit, but the stark number of pending litigations in India. Due to this major overhaul in the Indian judiciary, there is a gargantuan backlog of cases in India. ${ }^{9}$ As an inevitable consequence, the cases which are not pending before the courts take copious amounts of time to obtain a hearing let along the decision. Because of these problems the accused and their associates who are not made accused to the offences of honour killings get ample amounts of time to hamper and destroy evidence.

Also justice delayed is justice denied. For an incident of honour killing say which hypothetically took place in 1980, after all appeals and the entire matter is disposed off, takes close to 20 to 30 years for absolute disposal. In many instances, the family of the victim that wasn't involved in the killing of the victim loses faith and compliance with the strict procedural follow up becomes a bigger burden.

It is for this very requirement that fast track courts need to be set up to ensure that there is a speedy mechanism to handle all instances of honour killings. There is existing provision in the Code for Criminal Procedure that states that if the accused to the crime is not found guilty within a reasonable time then in such instances he shall be left free.

\section{Educate the Masses}

The father of the caste system in India is Manu. He said that the Brahmins, who are educated and are the spiritual superiors, form the head of the Hindu society. He then said that the dalits who are blue collar workforce or the peons and do menial jobs that require them to work in unhygienic conditions form the feet of the society. Everyone else fell in

\footnotetext{
${ }^{9}$ Shera Singh v. State of Punjab [1996SCALE(6)345]
} 
between of the two. These sayings of his led to the formation of the caste system in India which is one of the root factors and causes of honour killings in India.

To be able to nullify the teachings of Manu, there is a want for social mobility and access to education which would allow for members of the lower caste to be able to employ themselves in respectable terms and conditions of employment. Education would further enable to improve the quality of their work process irrespective of however menial it maybe.

A strong effort on the part of those educated can create access to good under graduate and graduate courses that would allow them to elevate their social standing. Moreover, a sound education would help communities and individuals to realize how superficial and meaningless class divisions on the basis of caste and stature really are. It would also create provision for better reflection on understanding the inherent nature of killing one's own family in preserving honour that lies on a very erroneous foundation.

\section{Create Awareness about the Futility of Honour Killings}

There are many parts of the vast Indian society to which the education system will not be able to pave its way. As instead of waiting for the same to happen, one can spread the dangers and arbitrariness in resorting to offences such as honour killings. Spreading awareness can again ensure that khappanchayats do not pass orders against the law or the public policy of India. Even if they do, then the right amount of awareness or information can ensure that individuals who are resident in areas can take the rightful measures to prevent such orders of the khap from taking action.

There are another two aspects of honour killing. One is honour and the other is the killing. Honour in itself is a relative and subjective word used to define the benchmark for acts and conduct which are conducive or accepted by the family. Anything else or beyond this subjective benchmark would result in the infringement of the honour of the family. Where there is no law that deals with the honour aspect of the violation, there is law that deals with the killing that results from such law on the infringement of such honour.

A heavy patriarchal shadow hangs over India, which subjugates the rights of women and results in a very harsh treatment of their freedom and independence in society. Men in the country believe that they own the daughters and treat them like property and objects. This is one of the main reasons for the instances of honour killings.

This is a question of a value system. Men and their family members need to realize that women are equally responsible for themselves as men and no one can lay claim to their independence and duties. This would allow for marriages and all other actions for which women are killed to be appreciated as acts being acted out of one's own and there would be a place for acceptance of such acts. Gender equality is of utmost importance so that the wills and desires of men and women are treated alike. No one sex is allowed to dominate its will over another. When men don't feel like their stronghold over another has not been weakened, then in such situations there wouldn't arise a desire to avenge the dishonor brought upon one's family. Also the situation where one or another member of the family feels like they enjoy certain position to have the entire family follow on their instruction would not arise.

\section{CONCLUSIONS}

In gender equity lies the most potent solution for most of the honour crimes. However, another very effective way of reducing the number of honour killings would be to create caste based equity. Members of particular castes believe in 
certain practices with respect to ceremonies for instance by virtue of which they believe themselves to be superior to other castes. On the annulment of the caste system, by education the coming generations about its futility would result into people from different caste systems interact, marry and involve in one another's activities in a positive fashion.

\section{REFERENCES}

1. "Honor killing: Definition and More from the Free Merriam-Webster Dictionary". Merriam-webster.com. December 31, 2013.

2. Yasmeen Hassan "The haven becomes hell: a study of domestic violence in Pakistan." August 16, 1995.72 p. (Special Bulletin),

3. Dendane, Z. O. U. B. I. R. (2013). The stigmatisation of the glottal stop in Tlemcen Speech Community: An indicator of dialect shift. International Journal of Linguistics and Literature (IJLL), 2(03), 1-10.

4. Johns Hopkins Bloomberg. Sheri \& Bob Stritof.Marriage.

5. Amnesty International, Amnesty International Report $1999-B$

6. Sinha, U. N. (2013). The impact of sound and environment on universe-A study [From the present in collaboration to the ancient Indian past]. Social Sciences (IJRANSS), 1(1), 1-8.

7. "Violence against Women and "Honor Crimes". Human Rights Watch. Retrieved 6 April 2001.

8. Vishesh Kocchar. Teen Lovers killed in India. Ibnlive. September 18, 2008. 